\title{
IPTEKS PENGUATAN BADAN PENELITIAN DAN PENGEMBANGAN DAERAH PROVINSI SULAWESI UTARA PASCA PENERAPAN PERATURAN PEMERINTAH TENTANG INOVASI DAERAH
}

\author{
Faisal Humiang ${ }^{1}$, Sheron H.R. Rimbing ${ }^{2}$, Alva O. Sumanti ${ }^{3}$, Winston Pontoh $^{4}$ \\ 1,2,3,4 Jurusan Akuntansi, Fakultas Ekonomi dan Bisnis, Universitas Sam Ratulangi, Jl. Kampus Bahu, Manado, \\ 95115, Indonesia \\ E-mail : faisalhumiang@gmail.com
}

\begin{abstract}
Article 386 paragraph 1 of Law Number 23 Year 2014 concerning Regional Government which made for increasing the regional government's performance. The innovation that took place in the city of Manado in 2016 was a successful innovation in the region. After the issuance of Government Regulation Number 38 of 2017 concerning Regional Innovation, it's stated that regional innovation is organized by the head of the Research and Development Agency $(R \& D)$. Applying a qualitative approach through literature studies. It aims to contribute ideas about various efforts that can be done by $R \& D$ of Manado City institutions in carrying out their functions in Government Regulation Number 38 of 2017 concerning Regional Innovation. Agencies must be the organization responsible for regional innovation by providing solutions for regional innovation, becoming the Independent Team Coordinator to deal with problems that occur in these countries. Agencies must carry out additional budgets to support tasks to improve the Regional Innovation System.
\end{abstract}

Keyword :Regional innovation, agency and governments.

\section{PENDAHULUAN}

Sebuah perkembangan dalam pengetahuan dan inovasi ialah faktor penting untuk menentukan perubahan ekonomi disuatu daerah. Hal itu dapat diwujudkan lewat pemahaman dari semua pihak tentang pentingnya inovasi agar terwujudnya perkembangan itu sendiri. Pengetahuan dan inovasi saling berhubungan namun, masyarakat menuntut kaitan antara pengetahuan dan inovasi tersebut terhadap kebutuhan ekonomi mereka. Untuk itu, pandangan sistem harus disesuaikan dengan kebutuhan semua pihak dalam pemajuan sistem. Pemerintah daerah juga harus berkewajiban dan mempunyai hak terutama dalam mengembangkan sistem inovasi didaerah masing-masing dan turut memperkuat keseseaian kebijakannya dalam kerangka nasional. Karena sistem inovasi daerah merupakan bagian penting dari sistem inovasi nasionil Indonesia. Selanjutnya yaitu kesiapan dari warga masyarakat untuk menerima program inovasi daerah juga sangat diperlukan agar program ini dapat berjalan dengan baik karna sudah melibatkan semua pihak. Pengembangan inovasi daerah diindonesia dinilai sangat penting, terutama hal yang saling berhubungan seperti kelemahan perkembangan sistem inovasi diindonesia pada saat ini. Hal pokok yang tidak dapat dibiarkan dalam proses tindakan berkaitan dengan inovasi daerah ialah perkembangan teknologi.

\section{TINJAUAN PUSTAKA}

Ruang Lingkup. Menurut Peraturan Menteri Dalam Negeri nomor 3 tahun 2012, ruang lingkup penguatan sistem inovasi daerah meliputi :

1. Konsep sistem inovasi daerah. Konsep ini berasal dari potensi-potensi di setiap daerah. Pemerintah melihat bahwa lewat pengembangan potensi-potensi di setiap daerah, maka daerah tersebut akan berkembang dan mencapai tingkat pertumbuhan ekonomi yang tinggi yang berimbas pada peningkatan kesejahteraan masyarakat. Konsep ini juga 
diberlakukan agar terciptanya peningkatan efisiensi, perbaikan efektifitas, perbaikan kualitas pelayanan dibidang pemerintahan serta mengutamakan kepetingan umum. Konsep ini juga tidak hanya menjadi program daerah melainkan juga program pemerintah pusat dalam rangka mewujudkan kemajuan bagi masyarakat dan daerah.

2. Susunan unsur sistem inovasi daerah. Penataan unsur sistem inovasi harus dilakukan secara sistemik menyangkut kerangka kerja, hubungan kelembagaan, iptek, budaya dan sumber daya. Kelembagaan yang dimaksud institusi pemerintah, pemerintahan daerah, lembaga kelitbangan, lembaga pendidikan, lembaga penunjang inovasi, dan dunia usaha. Sumber daya juga merupakan ketentuan yang mendukung penguatan sistem inovasi daerah guna mencapai peningkatan daya saing daerah. Budaya inovasi harus didorong oleh nilai- nilai profesionalisme para pelaku sistem inovasi daerah agar keunggulankeunggulan daerah mampu berkembang sesuai dengan potensi terbaik yang dimiliki.

3. Pengembangan sistem inovasi daerah. Pengembangan inovasi daerah meliputi cara berpikir yang strategis dan konsisten dengan kerangka jangka panjang. Strategi untuk mengembangkan inovasi daerah merupakan prioritas daerah untuk meningkatkan potensi, daya saing daerah dan kemajuan daerah agar dapat berimbas pada pertumbuhan ekonomi yang tinggi dan peningkatan kesejahteraan masyarakat. Untuk mencapainya pentingnya interaksi kemitraan dan peran masyarakat juga pemerintah untuk menghasilkan potensi kebijakan yang terkait dengan inovasi daerah tersebut.

\section{METODE PENERAPAN DAN TEKNIK PENERAPAN}

\subsection{Metode Penerapan Ipteks}

Metode penerapan yang digunakan untuk penguatan Badan Penelitian dan Pengembangan Daerah yaitu menurut Undang-Undang Nomor 18 Tahun 2002 dan Surat Mendagri Nomor 080/867/SJ Tanggal 11 April 2008 yang telah dikeluarkan.

\subsection{Teknik Penerapan Ipteks}

Meningkatkan kapasitas sumber daya manusia dalam Balitbangda Sulut melalui beberapa program seperti sosialisai dan pelatihan khusus kepada para pegawai.

\section{PEMBAHASAN}

\subsection{Gambaran Objek Penerapan Ipteks}

Kelitbangan adalah unsur penunjang urusan pemerintahan yang memiliki tugas membantu Gubernur mengerjakan fungsi penunjang urusan pemerintahan yang menjadi kewajiban daerah provinsi. Kelitbangan beralamat di Jl. 17 agustus teling atas kecematan Wanea Provinsi Sulawesi Utara Indonesia. Selain membantu Gubernur, tugasnya melakukan penelitian di berbagai sektor seperti pertanian, perternakan, kelautan, dan lainya yang menunjang perekonomian suatu daerah. Badan Penelitian dan Pengembangan Daerah dibentuk berdasarkan pertimbangan bahwa dalam rangka melaksanakan ketentuan pasal 4 Perda Provinsi Sulawesi Utara tentang susunan dan pembentukan Perangkat Daerah Provinsi Sulut, jadi Gubernur Sulawesi Utara harus menetapkan peraturan mengenai posisi, tugas dan fungsi serta tata kerja.

\subsection{Pembahasan}

Inovasi merupakan salah satu kebijakan pemerintah dalam rangka peningkatan daya saing daerah, peningkatan kapasitas pemerintah daerah, serta perluasan pertumbuhan ekonomi. Sistem inovasi pada dasarnya merupakan suatu kesatuan hubungan dari pemerintah, masyarakat, dan teknologi yang mempengaruhi arah perkembangan dan kecepatan inovasi. Tujuan pengembangan sistem inovasi daerah adalah sebagai berikut :

1. Memanfaatkan segenap potensi pembangunan secara efisiensi guna menghasilkan pertumbuhan ekonomi yang berkualitas

2. Mengembangkan daya saing ekonomi daerah melalui inovasi 
3. Memelihara daya dukung dan kualitas lingkungan

4. Menciptakan iklim investasi yang mendukung untuk menarik investor

5. Menciptakan kebijakan berdasarkan asas keberlanjutan yang bewawasan lingkungan

6. Perlindungan terhadap sektor-sektor ekonomi lokal yang daya saingnya masih rendah dan menciptakan daya tarik investor

7. Menciptakan kemajuan daerah

Kriteria inovasi daerah memberi manfaat bagi daerah atau masyarakat, tidak menimbulkan pembatasan kepada masyarakat, merupakan unsur pemerintahan yang menjadi kewenangan daerah, mengandung sebebagian unsur dari inovasi. Peran badan penelitian dan pengembangan daerah dalam upaya penguatan inovasi daerah :

1. Memberi masukan terhadap dasar perubahan daerah. Dalam hal ini badan penelitian dan pengembangan daerah harus memahami inovasi dan penilaian pembaharuan manfaat untuk daerah dan masyarakat

2. Menyatukan pemikiran atau gagasan dari perangkat daerah dalam melaksanakan tugas ini. Balitbangda harus mempunyai kemampuan berkomunikasi yang baik dan memiliki kemampuan menindaklanjuti inovasi serta melakukan penyampaian inovasi dari perangkat daerah menuju ke kepala daerah

3. Mengumpulkan pemikiran yang bersumber dari masyarakat. Untuk hal ini, lembaga harus melakukan review atas inovasi daerah

4. Melaksanakan fungsi dari evaluasi

5. Penerimaan laporan secara teratur tentang pelaksanaan inovasi daerah.

\section{KESIMPULAN DAN SARAN}

\subsection{Kesimpulan}

Untuk memperkuat dalam menerima inovasi daerah, maka Balitbangda Sulut harus mempunyai pemahaman tentang apa itu inovasi daerah dengan berbagai kriterianya, mempunyai terobosan baru mengenai hal-hal yang dihadapi pemerintah daerah, juga harus mempunyai kemampuan koordinatif dan komunikasi yang baik, dan kemampuan verifikasi yang baik dan benar serta evaluasi, agar mampu mewujudkan inovasi daerah sesuai Peraturan Pemerintah No. 38 Tahun 2017.

\subsection{Saran}

Perlu adanya dukungan dari semua pihak dalam Balitbangda, saling toleransi baik itu atasan dengan atasan, atasan dengan bawahan, dan bawahan dengan bawahan dan serta kesadaran yang tinggi agar mampu memperkuat instansi Balitbangda dalam mewujudkan inovasi daerah sesuai dengan peraturan pemerintah yang sudah ditetapkan. Sumber daya manusia juga merupakan kunci utama dalam mewujudkan inovasi daerah ke arah lebih baik.

\section{DAFTAR PUSTAKA}

Arifin, dkk. 2003. Inovasi Teknologi dalam Pengembangan Ekonomi Lokal. Jakarta: IPB Press.

Alva,. Edy,. Tontowi. Desain Produk Inovatif \& Inkubasi Bisnis Kompetitif. Yogjakarta : UGM Press.

Badan Penelitian dan Pengembangan Daerah. Visi Misi Balitbangda Sulut. http://balitbangda.sulutprov.go.id/hal-visi-misi.html

Kurniawan, T., dan Hasan, A. (2005). Efisiensi Anggaran Sebagai Faktor Kunci Keberhasilan dalam Pelaksanaan Program Inovasi di Kabupaten Jembrana. Jurnal Ilmu Administrasi, 5(2), 77-189. 
Mariana, D. (2010). Otonomi Daerah dan Inovasi Kebijakan. Jurnal Ilmu Pemerintahan, 1(1), 14-20.

M, Fathur, Rohman. 2016. Konsep, Metode \& Strategi Inovasi Sektor Publik. Malang: AFJBooks

Narutomo, T. (2014). Program Penguatan Sistem Inovasi Daerah (SIDa) Sebagai Exit Strategy Program Nasional Pemberdayaan Masyarakat (PNPM). Jurnal Bina Praja, 6(2), 143-156.

Pemerintah Provinsi Sulawesi Utara. 2016. Peraturan Gubernur Sulawesi Utara Nomor 84 Tahun 2016 Tentang Kedudukan, Susunan Organisasi, Tugas dan Fungsi, Serta Tata Kerja Badan Penelitian dan Pengembangan Daerah Provinsi Tipe C. Sulawesi Utara.

Pemerintah Republik Indonesia. Permendagri Nomor 3 Tahun 2012. Tentang Penguatan Sistem Inovasi Daerah. Jakarta.

Pemerintah Republik Indonesia. Peraturan Pemerintah Nomor 79 Tahun 2005 TentangPedoman Pembinaan dan Pengawasan Penyelenggaraan Pemerintahan Daerah. Jakarta.

Prasojo, J., Kurniawan, T. dan Hasan, A. (2004). Peran Kepemimpinan Dalam Program Inovasi Daerah. Jurnal Ilmu Administrasi dan Organisasi Bisnis dan Birokrasi, 2(4), 641-647.

R, Soeprapto. 2003. Pengembangan Kapasitas Pemerintah Daerah Menuju Good Governance. Jakarta. Indonesia.

Resen, M. (2015). Refleksi dan Pengaturan Inovasi Daerah. Jurnal Magister Hukum Udayana, 4(4), 680-687. 